\title{
Synthesis of a Growth-Associated Protein by Embryonic Rat Cerebrocortical Neurons in vitro
}

\author{
Nora I. Perrone-Bizzozero, ${ }^{\star}$ Seth P. Finklestein, $\dagger$ and Larry I. Benowitz ${ }^{\star} \ddagger$ \\ Mailman Research Center, McLean Hospital, Belmont, Massachusetts 02178; †Department of Neurology, \\ Massachusetts General Hospital; and Departments of *Psychiatry and †Neurology, and łProgram in \\ Neuroscience, Harvard Medical School
}

Proteins synthesized by embryonic rat cortical cultures were studied under conditions that were either permissive or nonpermissive to neurite outgrowth. Freshly dissected cortex from embryonic day 17 rat pups was mechanically dissociated and plated on poly(L-lysine) substrate in the presence of (1) serum-free media, which allowed neuronal survival but no outgrowth; (2) serum, which allowed survival of both neurons and glia as well as neurite outgrowth; or (3) a hormone-supplemented defined media, which allowed preferential survival and outgrowth of neurons. In addition, postnatal tissue was cultured as a source of glia. Cultures were pulse-labeled with ${ }^{35}$ S-methionine $48 \mathrm{hr}$ after plating and the protein synthesis patterns examined by 2-dimensional gel electrophoresis followed by fluorography. The expression of an acidic $50 \mathrm{kDa}$ protein, associated with the particulate fraction of cells, was found to be a prominent correlate of neurite outgrowth. This protein was synthesized in serum- or hormone-treated embryonic cultures showing neurite outgrowth but was undetectable in embryonic cultures without outgrowth or in postnatal glial cultures. By virtue of its migration position on 2-dimensional gels, its presence in a light membrane fraction, and its cleavage products after Staphylococcus aureus protease treatment, the $50 \mathrm{kDa}$ protein appears to be identical to an acidic 43-49 $\mathrm{kDa}$ protein that has been identified in several developing and regenerating neural pathways, as well as to the B-50 phosphoprotein. These findings lend support for a critical role of this protein in neural development and demonstrate the feasibility of using primary CNS cell cultures to study its biosynthesis and function.

Studies in both lower vertebrates and mammals have identified a group of membrane proteins whose synthesis and axonal transport are high when neuronal connections are forming but that then decline with maturation (Skene, 1984). Prominent among these so-called growth-associated proteins is a highly acidic protein with a molecular weight on SDS-PAGE estimated between 43 and $49 \mathrm{kDa}$. Relative to the mature state of neurons, the labeling of this protein is $1-2$ orders of magnitude greater during the initial development of neural connections (Skene and Willard, 1981b) or in neurons that are undergoing axonal regeneration (Benowitz and Lewis, 1983; Skene and Willard, 1981a). A protein of similar molecular weight and isoelectric point is

\footnotetext{
Received Mar. 24, 1986; revised June 9, 1986; accepted June 19, 1986.

This work was supported by grants from the National Eye Institute NIH R01 EY05690), the Marion Benton Trust, and a Grant-in-Aid from the American Heart Association, with funds contributed by its Virginia affiliate. We thank Martha Shea for help in preparing the manuscript and Ken Moya for assistance in the phosphorylation experiments.

Correspondence should be addressed to Dr. Larry I. Benowitz, Mailman Rcsearch Center, McLean Hospital, 115 Mill Street, Belmont, MA 02178.

Copyright (C) 1986 Society for Neuroscience $0270-6474 / 86 / 123721-10 \$ 02.00 / 0$
}

enriched in neural growth cones (pp-46; Katz et al., 1985), and this in turn appears to be identical to the presynaptic membrane phosphoprotein identified in mammalian brain as B-50 (DeGraan et al., 1985; Gispen et al., 1985; Zwiers et al., 1980, 1985) or F-1 (Nelson and Routtenberg, 1985; Nelson et al., 1985; Routtenberg and Ehrlich, 1975).

Because of the ease of manipulating the extracellular environment and of visualizing aspects of cellular differentiation, primary neuronal cell cultures offer several advantages for studying the genetic regulation and functional significance of growthassociated proteins. In the present study, we examined proteins synthesized by embryonic rat cerebrocortical neurons in vitro under conditions that were either permissive or nonpermissive to neurite outgrowth. We report that expression of a $50 \mathrm{kDa}$ acidic protein is one of the principal correlates of neurite outgrowth and, moreover, that this protein comigrates with, and has similar proteolytic digestion fragments as, the membranebound phosphoprotein B-50 (F-1; pp-46).

\section{Materials and Methods}

\section{Culture methods}

Frontal cortex was dissected from embryonic day (E) 17 Sprague-Dawley rat embryos and stripped of meninges in Hank's buffered salt solution (HBSS; Gibco Laboratories, Grand Island, NY). The tissue was minced and dissociated in Minimal Essential Medium (MEM) containing Earle's salts and L-glutamine (GIBCO), with added glucose $(600 \mathrm{mg} \%)$, glutamine ( $2 \mathrm{~mm})$, vitamins (1X; GIBCO), and gentamycin $(10 \mu \mathrm{g} / \mathrm{ml})$, by repeated gentle trituration through a Pasteur pipette. Cells were seeded on $60 \times 15 \mathrm{~mm}$ culture dishes (Falcon Primaria, Becton-Dickinson Labware, Oxnard, CA) precoated with poly(L-lysine) (Sigma, St. Louis, MO) at a density of $2.4 \times 10^{6}$ cells/plate. Embryonic cultures were grown under 1 of 3 conditions: (1) in culture media alone ("serumfree"), which at the cell densities plated permitted neuronal survival but no outgrowth; (2) in the presence of $5 \%$ fetal calf $/ 5 \%$ heat-inactivated horse serum (GIBCO), which permitted both neuronal and glial survival and differcntiation, including abundant ncuritc outgrowth; or (3) in the presence of a defined "hormone supplement" (containing insulin, $5 \mu \mathrm{g}$ / $\mathrm{ml}$; transferrin, $1 \mu \mathrm{g} / \mathrm{ml}$; hydrocortisone, $20 \mathrm{nM}$; and 3,3',5-triiodo-Lthyronine, $0.3 \mathrm{nM}$; Müller et al., 1984) that permitted the preferential survival of neurons as well as neurite outgrowth. In addition, cerebral cortex from postnatal $(\mathbf{P} 2)$ rats was dissociated and plated in the presence of $5 \%$ fetal calf $/ 5 \%$ heat-inactivated horse serum to provide cultures that contained predominantly glia (Rudge et al., 1985). In some instances, parallel cultures were plated on poly(L-lysine)-coated 8-well glass tissue culture slides (Lab-Tek, Miles Scientific, Naperville, IL) for subsequent tetanus toxin immunostaining. These cultures were plated at a lower density (ca. 2000 cells/well) so that individual cells could be reliably distinguished.

Cultures were incubated at $37^{\circ} \mathrm{C}$ in a $95 \%$ air $/ 5 \% \mathrm{CO}_{2}$ humidified atmosphere. Most cultures were labeled and harvested at $48 \mathrm{hr}$; thosc surviving longer were given fresh medium every $3 \mathrm{~d}$, as well as cytosine arabinoside (10 $\mu \mathrm{M}$; Sigma) to suppress glial overgrowth. 
Table 1. Summary of cell culture conditions

\begin{tabular}{|c|c|c|c|c|}
\hline & & & Neurite & $\begin{array}{l}\text { Pro- } \\
\text { tein } \\
\text { "r" }\end{array}$ \\
\hline $\begin{array}{l}\text { Culture } \\
\text { condition }\end{array}$ & $\begin{array}{l}\text { Cell } \\
\text { survival }^{*}\end{array}$ & $\begin{array}{l}\text { Protein } \\
\text { labeling }\end{array}$ & $\begin{array}{l}\text { out- } \\
\text { growth }\end{array}$ & $\begin{array}{l}\text { syn- } \\
\text { thesis }\end{array}$ \\
\hline
\end{tabular}

E17

$\begin{array}{lrrrr}\text { serum-free } & 807 \pm 130 & 61 \pm 16 & - & - \\ \text { serum } & 1122 \pm 185 & 1200 \pm 17 & ++ & ++ \\ \text { hormone } & & & & \\ \quad \text { supplement } & 841 \pm 35 & 193 \pm 7 & + & + \\ \text { P2: serum } & ()^{c} & 1300^{d} & - & -\end{array}$

${ }^{a}$ Estimated total number of cells/plate, in thousands, based on counting 2 fields in cultures parallel to those used to study protein synthesis.

${ }^{h}$ In thousands of counts per minute incorporated into hot TCA-insoluble protein. Values represent means \pm range from aliquots of duplicate cultures pulse-labeled for $1 \mathrm{hr}$ in $70 \mu \mathrm{Ci}$ of ${ }^{35} \mathrm{~S}$-methionine/ml, $2 \mathrm{~d}$ after plating.

c Density too high to count (glial proliferation occurs under this condition).

${ }^{d}$ Not counted: estimated from density of fluorograms.

\section{Cell staining}

Cultures taken for morphological analysis were examined first under phase-contrast microscopy after the addition of trypan blue (final concentration, $0.2 \%)$ and were then fixed and stained by the addition of formalin (final concentration, $10 \%$ ), followed by $0.1 \%$ Coomassie blue (Sigma) in 50\% methanol $/ 10 \%$ acetic acid. Stained plates were examined with a light microscope (Zeiss Universal, F.R.G.) equipped with a video imaging system (Quandens; Fite, Inc., Brunswick, ME; magnification, $1285 \times)$. The mean number of cells counted in each of 2 representative fields (without microaggregates) was multiplied by the number of fields/ plate to provide an estimate of the total number of cells per plate.

Cells plated on glass slides were incubated with tetanus toxin $(2 \mu \mathrm{g} /$ $\mathrm{ml}$; Calbiochem, San Diego, CA) for $30 \mathrm{~min}$ at $37^{\circ} \mathrm{C}$, washed with PBS, pH 7.4, with $0.5 \%$ BSA (Sigma), and fixed with $2 \%$ paraformaldehyde. They were stained by the successive addition of human tetanus immune globin (1:1000; Massachusetts Public Health Laboratories, Boston), affinity-purified biotin-conjugated goat anti-human IgG (1:200; Vector Laboratories, Burlingame, CA), avidin-biotin complex (Vector), and diaminobenzidine (DAB; Sigma). Washes between steps were done in PBS with $0.5 \%$ Triton-X (Sigma). The slides were dried, coverslipped, and examined under a light microscope. Some wells were processed without either toxin, primary, or secondary antibody as controls for nonspecific staining.

\section{Cell labeling}

Duplicate cultures for each experimental condition were washed with methionine-free media (MEM Selectamine Kit; GIBCO) and labeled in this same medium containing ${ }^{35} \mathrm{~S}$-methionine $(40-70 \mu \mathrm{Ci} / \mathrm{ml}$; NEG$009 \mathrm{~T}$, New England Nuclear/DuPont, $1000 \mathrm{Ci} / \mathrm{mmol}$ ) for $1 \mathrm{hr}$ at $37^{\circ} \mathrm{C}$ in a $95 \%$ air $/ 5 \% \mathrm{CO}_{2}$ humidified environment. Cells were then washed with media containing an excess of nonradioactive methionine (MEM; GIBCO) and incubated in this medium for an additional $1 \mathrm{hr}$. Both incubations also contained the appropriate concentrations of dialyzed serum or hormone supplement, as above. Following incubation, cells were washed with PBS containing $2 \mathrm{~mm}$ methionine ( $\mathrm{pH} \mathrm{7.4)} \mathrm{and} \mathrm{har-}$ vested in sucrose buffer $(0.32 \mathrm{M}$ sucrose, $50 \mathrm{~mm}$ Tris- $\mathrm{HCl}, 10 \mathrm{~nm}$ deoxyribonuclease, $10 \mathrm{~nm}$ ribonuclease, $\mathrm{pH} 7.4,0-4^{\circ} \mathrm{C}$ ).

\section{Subcellular fractionation}

For most of the studies, incorporation of labeled methionine into proteins of the total particulate and cytosol fractions of cells was examined. Tissue was homogenized in a glass-Teflon system $(5000 \mathrm{rpm}, 10$ strokes, $0.25 \mathrm{~mm}$ gap, $0-4^{\circ} \mathrm{C}$ ) and the homogenate centrifuged at $100,000 \times g$ for $1 \mathrm{hr}$. The resulting pellet (total particulate fraction) was lyophilized, while the supernatant (cytosol fraction) was dialyzed extensively against $50 \mathrm{~mm}$ ammonium acetate before being lyophilized. Samples were stored at $-70^{\circ} \mathrm{C}$.

In some studies, a light membrane fraction was prepared using a procedure similar to that described by Pfenninger et al. (1983) and
DeGraan et al. (1985) to prepare a fraction enriched in neuronal growth cones. Cells were homogenized in an excess of sucrose buffer (as above, but containing $1 \mathrm{mM} \mathrm{MgCl})$, centrifuged at $1600 \times g(10 \mathrm{~min})$, and the resulting supernatant layered onto $0.75 \mathrm{M}$ sucrose (buffered as above). Samples were centrifuged at $130,000 \times g$ for $2.5 \mathrm{hr}$; material sedimenting at the $0.32 / 0.75 \mathrm{M}$ sucrose interface was collected, diluted 10 fold in hypoosmotic buffer, and recentrifuged at $20,000 \times \mathrm{g}$ for $30 \mathrm{~min}$. The resulting pellet was lyophilized and stored at $-70^{\circ} \mathrm{C}$.

In other studies, a synaptosomal plasma membrane (SPM) fraction was obtained from neonatal rat brain. Brains of P2 rats were homogenized in sucrose buffer (10:1 buffer volume, wet weight tissue), centrifuged at $1000 \times g(10 \mathrm{~min})$, the pellet discarded, and the supernatant recentrifuged at $17,000 \times g$ for $30 \mathrm{~min}$. The resulting "crude membrane" pellet was lyzed by trituration in hypoosmotic buffer ( 20 passes over a $1 \mathrm{hr}$ period through a 27 gauge needle; $10 \mathrm{~mm}$ Tris- $\mathrm{HCl}, \mathrm{pH} \mathrm{7.4,}$ $5 \mathrm{~mm}$ EGTA, $5 \mathrm{mM} \mathrm{MgCl}_{2}, 0-4^{\circ} \mathrm{C}$ ), loaded onto a discontinuous sucrose gradient ( $0.6-1.2 \mathrm{M}$ sucrose in same buffer), and centrifuged at $100,000 \times \mathrm{g}$ for $2.5 \mathrm{hr}$ using a SW-27 rotor (Sorvall). Material collected at the 0.6/ $1.2 \mathrm{M}$ sucrose interface was diluted 10 - to 20 -fold in hypoosmotic buffer, centrifuged at $20,000 \times g(20 \mathrm{~min})$, and the pellet collected and lyophilized for subsequent use.

\section{Gel electrophoresis}

Proteins were separated by 2-dimensional (2D) gel electrophoresis using the procedure of O'Farrell (1975) modified as described previously (Benowitz and Lewis, 1983). Samples were solubilized in lysis buffer containing $6 \%$ ampholines in a ratio of $2: 2: 1, \mathrm{pH} 3.5-5, \mathrm{pH} 5-7, \mathrm{pH} 3.5-$ 10 (LKB Instruments, Inc., Gaithersburg, MD), 9.5 M urea (SchwarzMann), $5 \% \beta$-mercaptoethanol (BioRad), and 2\% NP-40 (Nonidet P-40, Particle Data Laboratories, Inc., Elmhurst, IL) at $25-30^{\circ} \mathrm{C}$ and were loaded onto isoelectric focusing (IEF) gels (containing 6\% ampholines in the ratio above). Gels were run for $16 \mathrm{hr}$ at $300 \mathrm{~V}$, then for $4 \mathrm{hr}$ at $400 \mathrm{~V}$. Following equilibration (O'Farrell, 1975), IEF gels were placed onto the stacking gel above a 5-15\% linear gradient SDS-polyacrylamide slab gel (height, $25 \mathrm{~cm}$; thickness, $1.5 \mathrm{~mm}$ ) in a Hoefer $\mathrm{SE} 620$ apparatus. Electrophoresis was carried out at $15-20 \mathrm{~mA} / \mathrm{gel}$ until the dye front was $8 \mathrm{~cm}$ from the bottom. Molecular weight standards $(205,116,97.4,66$, $45,29,20$, and $14.3 \mathrm{kDa}$; BioRad) were run alongside each IEF gel.

Gels prepared for fluorography were fixed in $50 \%$ methanol- $10 \%$ acetic acid and stained with Coomassie Brilliant Blue (BioRad, R-250). Fixed gels were rinsed in water $(3 \times 15 \mathrm{~min})$, impregnated with $\mathrm{Au}$ tofluor (National Diagnostics, Somerville, NJ), vacuum-dried on Whatman \#1 filter paper, and set against Kodak X-OMat AR X-ray film at $-70^{\circ} \mathrm{C}$. When radiolabeled proteins were to be cut from gels for further use, unfixed gels were rinsed briefly in $\mathrm{H}_{2} \mathrm{O}(2 \times 10 \mathrm{~min})$ immediately after completion of electrophoresis and processed directly for fluorography. In some cases, gels containing 50-100 $\mu \mathrm{g}$ of nonradioactive proteins were stained with the reduced silver method in order to visualize steady-state levels of proteins at a high level of sensitivity (Oakley et al., 1980).

\section{Protein phosphorylation}

Samples of the neonatal rat cortical SPM fraction or of the total particulate fraction from serum-treated E18 cortical cultures, containing $200 \mu \mathrm{g}$ protein each, were suspended in $200 \mu \mathrm{l}$ of buffer $(20 \mathrm{~mm}$ HEPES, pH 7.3, 10 mм $\mathrm{MgCl}_{2}, 1 \mathrm{~mm}$ DTT, 0.4 mм EGTA buffered to pH 7.4, $0.7 \mathrm{mM} \mathrm{CaCl}$ ). After a $1 \mathrm{~min}$ preincubation at $30^{\circ} \mathrm{C}$, labeling was initiated by addition of $20 \mu \mathrm{Ci}{ }^{35} \mathrm{~S}-\mathrm{PO}_{3} \mathrm{~S}^{*}-\gamma-\mathrm{ATP}$ (NEG-027, New England Nuclear/DuPont) plus $5 \mu \mathrm{M}$ unlabeled ATP. Samples were labeled for $2 \mathrm{~min}$ at $30^{\circ} \mathrm{C}$. The reaction was terminated by quick freezing to $-70^{\circ} \mathrm{C}$ on dry ice, followed by lyophilization and storage at $-70^{\circ} \mathrm{C}$ for subsequent analysis on $2 \mathrm{D}$ gels.

\section{Comigration experiments}

Similarity between a protein synthesized in embryonic cultures and a phosphoprotein from neonatal rat brain was determined by eluting the proteins from their original gels and then coelectrophorising them on 2D gels. Unfixed 2D gels of complex protein mixtures were impregnated with Autofluor and vacuum-dried onto filter paper; reference marks were made with radioactive ink. Proteins of interest were identified by fluorography and cut from the gels by matching reference marks on films and gels. Cut gel pieces $\left(\sim 30 \mathrm{~mm}^{2}\right)$ were homogenized in $200 \mu \mathrm{l}$ of lysis buffer (see above) and loaded onto IEF gels, either separately or mixed. In all comigration experiments, samples were also mixed with $150 \mu \mathrm{g}$ 

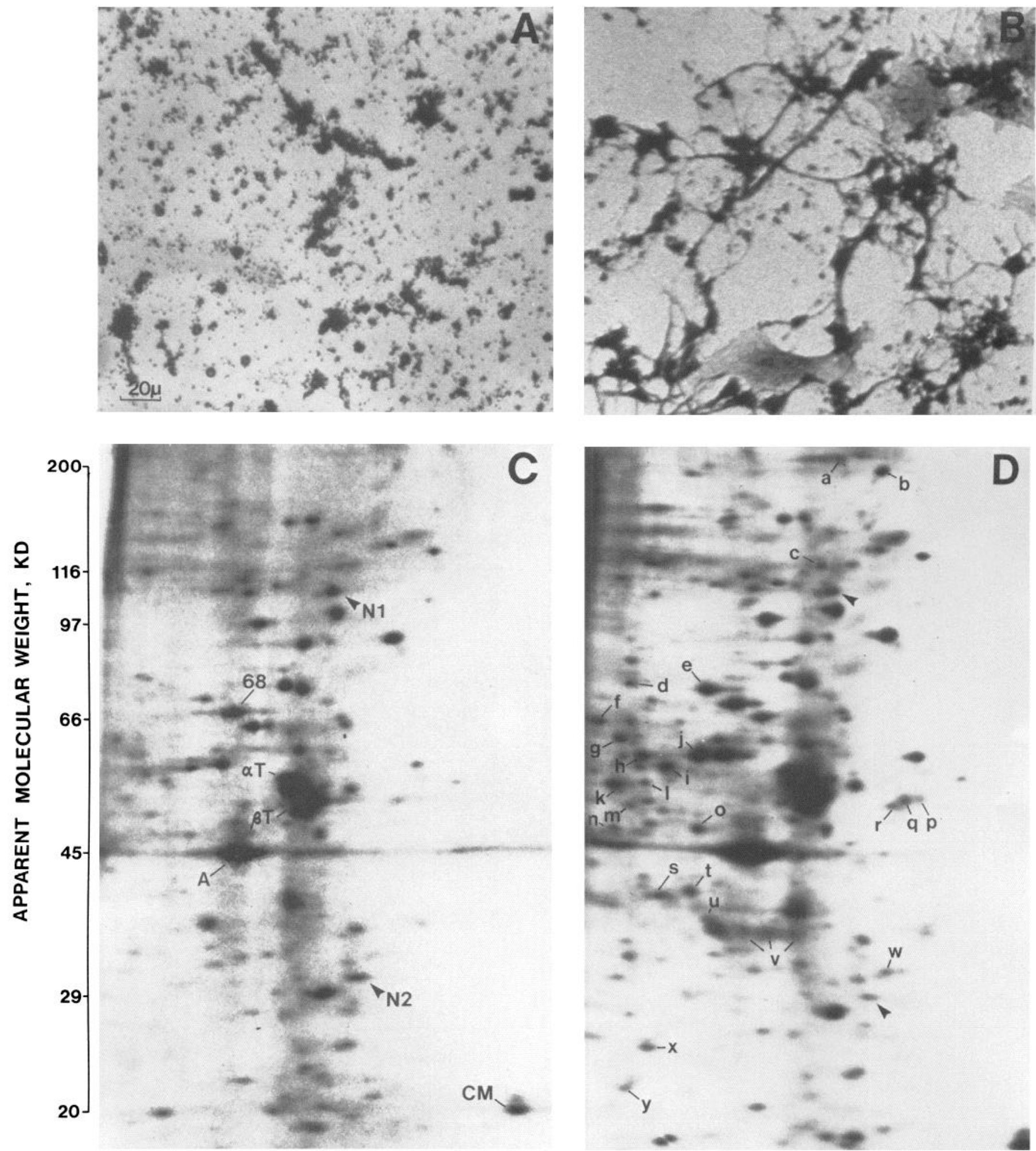

6.5

ISOELECTRIC POINT

4.1

Figure 1. Cellular morphology and protein synthesis patterns of cerebrocortical cultures. At $48 \mathrm{hr}$ after plating, Coomassie-stained embryonic cultures grown in serum-free media $(A)$ showed small, rounded cell bodies without processes. Particulate proteins synthesized by these cultures $(C)$ include high levels of actin $(A), \alpha$ - and $\beta$-tubulin $(\alpha T, \beta T)$, the $68 \mathrm{kDa} 5.6$ protein, and calmodulin $(C M)$. Serum-treated cultures of the same age $(B)$ show differentiation of neurons (densely stained, small pyramidal cell bodies with processes) and glia (larger, less densely stained cells with multiple nucleoli). Particulate proteins synthesized by serum-treated cultures $(D)$ show a number of specific labeling changes relative to the undifferentiated state $(a-y, D)$. Arrows point to positions of 2 proteins, N1 and N2, that appear to be neuronal markers whose expression is independent of process outgrowth. Fluorograms are representative of 4 independent replications. 

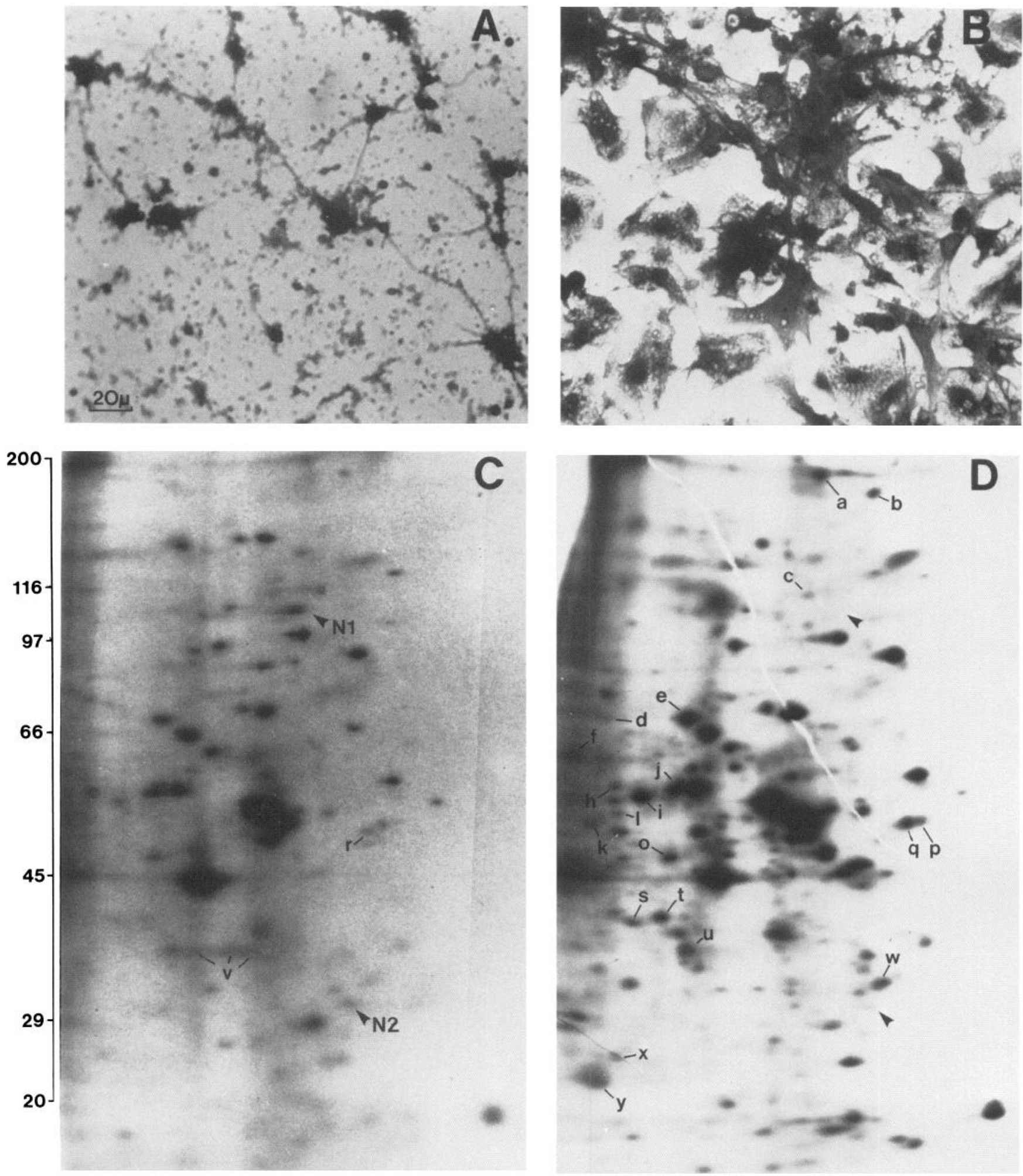

Figure 2. Cellular morphology and protein synthesis patterns of cerebrocortical cultures. At $48 \mathrm{hr}$, Coomassie-stained embryonic cultures plated in "hormone-supplemented" defined media $(A)$ showed neurite outgrowth and an absence of glia. Fluorograms of particulate proteins from these cultures $(C)$ were similar to those of undifferentiated cultures (Fig. 1C) except for the presence of proteins " $r$ " and "v." Serum-treated cultures of postnatal cerebral cortex contained mainly glia $(B)$. Particulate proteins from glia-enriched cultures $(D)$ showed the majority of proteins synthesized by serum-treated embryonic cultures but did not include proteins " $r$ " and "v." Arrows indicate the positions of N1 and N2, the presumptive neuronal markers. Fluorograms are representative of 2 independent experiments. 
of unlabeled SPM fraction from neonatal rat brain in order to examine the relationship between labeled proteins of interest and normal membrane components as visualized by Coomassie blue staining.

\section{Proteolytic digestion}

A second means of comparing different proteins involved analysis of enzyme cleavage products (Cleveland, 1983). Radiolabeled proteins were cut from unfixed 2D gels, homogenized in $150 \mu$ l SDS-PAGE solubilization buffer $(125 \mathrm{~mm}$ Tris- $\mathrm{HCl}, \mathrm{pH} 6.8,0.1 \%$ SDS, $10 \%$ glycerol, 1 mм EGTA, $0.3 \% \beta$-mercaptoethanol, trace bromphenol blue) and loaded into wells of a $3 \%$ acrylamide stacking gel ( $\mathrm{pH} 6.8$ ) above an SDS$15 \%$ polyacrylamide running gel $(25 \mathrm{~cm}$ in length, $\mathrm{pH} 8.8)$. Staphylococcus aureus protease (Sigma), concentrated in the same buffer, was added to a final concentration of $40 \mu \mathrm{g} / \mathrm{ml}$ in the sample wells. After allowing $1 \mathrm{hr}$ for the reaction to begin, gels were run overnight at $70 \mathrm{~V}$. Gels were stained, fixed, impregnated with Autofluor, and set against film to visualize migration positions of cleavage products.

\section{Results}

\section{Cellular characteristics and protein synthesis patterns of} cerebrocortical cultures

The characteristics of dissociated rat cerebrocortical cultures at $48 \mathrm{hr}$ after plating are summarized in Table 1 . The majority $(>90 \%)$ of cells cultured under each condition was viable, as assessed by trypan blue exclusion under phase-contrast microscopy. Accordingly, the number of cells counted after fixation and staining was taken as an index of cell survival, expressed as the estimated total number of cells/plate in Table 1 . These values ranged between 30 and $50 \%$ of the number of cells initially plated, consistent with previously reported values (Varon et al., 1983/1984). Cell survival was highest in serum-treated cultures and $20-25 \%$ less in cultures in serum-free or "hormonesupplemented" media. The viability of cultures was further confirmed by their ability to incorporate ${ }^{35} \mathrm{~S}$-methionine into proteins (Table 1).

Initial studies examined the pattern of protein synthesis associated with serum-induced cellular differentiation. At $48 \mathrm{hr}$ after plating, Coomassie-stained embryonic cortical cultures grown in serum-free media showed small undifferentiated cell bodies without process outgrowth (Fig. 1A). Immunostaining of parallel cultures on glass slides showed that the majority of these cells were stained darkly for tetanus toxin binding sites, suggesting their neuronal identity. (No staining was seen when the toxin or any antibody was omitted from the staining procedure.) These results are consistent with previous studies showing neuronal predominance in embryonic brain cultures plated under serum-free conditions (Barbin et al., 1984). By contrast, Coomassie-stained embryonic cultures plated for $48 \mathrm{hr}$ in the presence of serum showed small polygonal cells with abundant process outgrowth as well as large flatter cells (Fig. 2B). Parallel cultures stained with tetanus toxin showed dense specific staining of many of the small cells with process outgrowth confirming their neuronal identity, and faint nonspecific staining of the

Figure 3. Synthesis of the protein " $r$ " in cerebrocortical cultures. Enlargements of the 2D gel fluorograms from Figures 1 and 2. The " $r$ " protein $(50 \mathrm{kDa}, \mathrm{pI} 4.7)$ is identified by its location midway between the dotted lines drawn through 2 heavily labeled reference proteins $\left({ }^{*}\right)$ and by its position relative to proteins "p" and "q." [Note that protein " $\mathrm{z}$," seen on some gels ( $B, D$; and Fig. 4, lower right), is distinguished from " $r$ " by these criteria.] Synthesis of protein " $r$ " is seen in the particulate fraction of serum- $(B)$ or hormone- $(C)$ treated embryonic cultures with neurite outgrowth but not in undifferentiated cultures grown in serum-free media $(A)$ nor in postnatal glia-enriched cultures $(D)$. The protein is not present in the cytosol fraction of serum-treated embryonic cultures $(E)$.
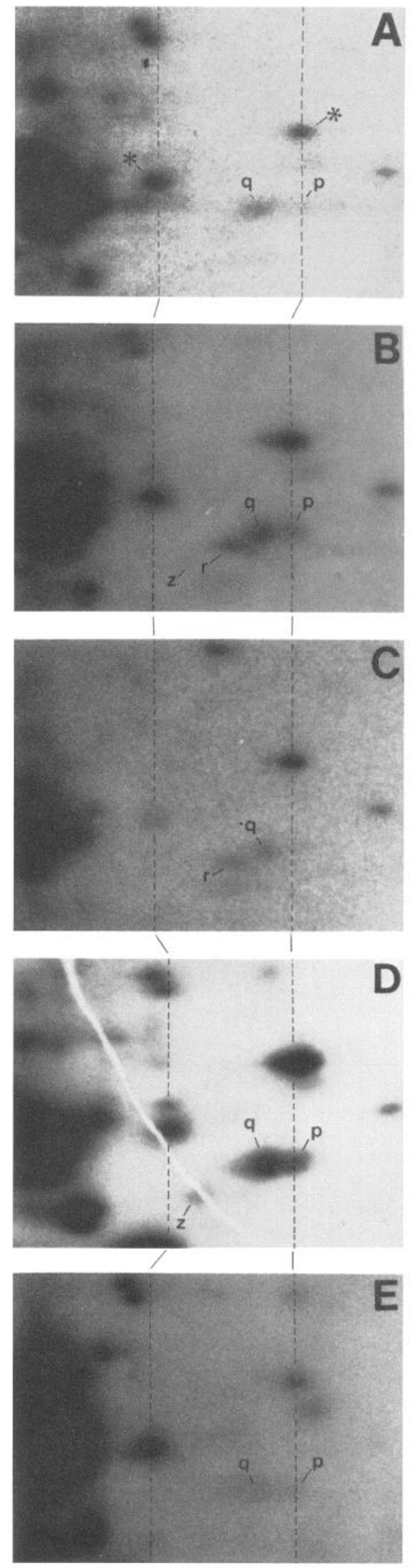

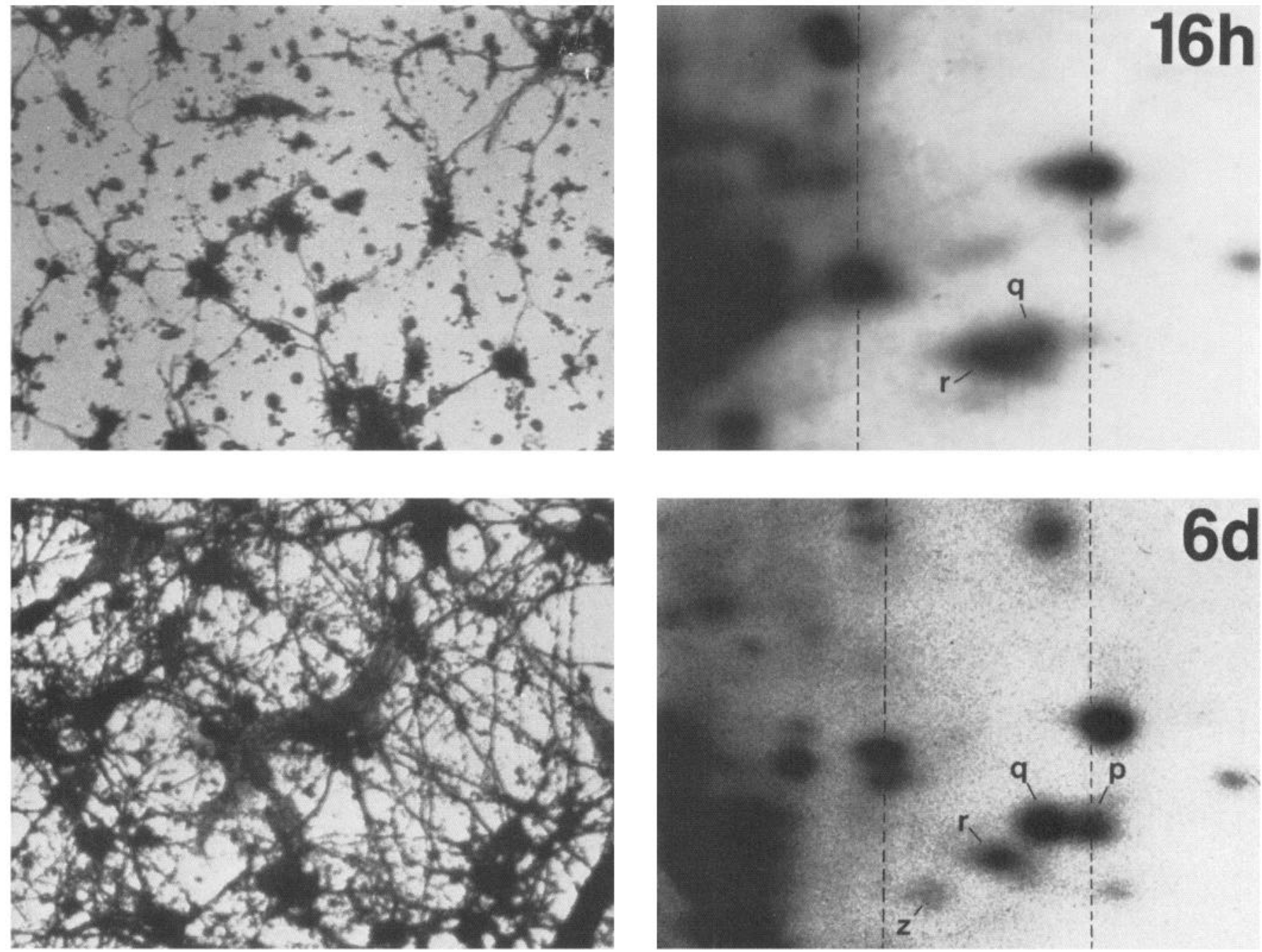

Figure 4. Time course of protein " $\mathrm{r}$ " synthesis. Serum-treated embryonic cultures showed neurite outgrowth as early as $16 \mathrm{hr}$ ( $u$ pper left) and as late as $6 \mathrm{~d}$ (lower left) after plating. Abundant synthesis of protein " $\mathrm{r}$ " was found at both time points (upper and lower right, respectively). (Note the distinction of protein " $r$ " from " $\mathrm{z}$ " (lower right; see also Fig. $3 D$ ).)

larger cells, presumably glia or other non-neuronal elements. These findings are in agreement with previous studies showing both neuronal and glial survival and differentiation in embryonic cultures in the presence of serum (Raff et al., 1979). Particulate proteins synthesized by serum-free, undifferentiated cultures (Fig. 1C) included $\alpha$ - and $\beta$-tubulin ( $\alpha$-T and $\beta$-T), actin (A), a $68 \mathrm{kDa}$ pI 5.6 protein, and calmodulin (Gilbert and Strocchi, 1983; Gilbert et al., 1981; Strocchi et al., 1984). Serumtreated differentiated cultures expressed most of the same proteins, as well as several that were not detected or detected only at low levels, in serum-free undifferentiated cultures $(a-y$, Fig. $1 D$ ). N1 and N2 are proteins whose labeling is relatively higher in serum-free than in serum-treated cultures, and which can thus be considered as neuronal markers that are independent of process outgrowth.

In an effort to determine the cellular origin of proteins induced by serum treatment, 2 additional culture conditions were examined. The first employed a "hormone-supplemented" defined medium (containing hydrocortisone and tri-iodothyronine) that has been reported to promote the preferential survival of neurons (Müller et al., 1984) and, at the cell densities plated, also resulted in marked neurite outgrowth (Fig. $2 A$ ). In the second condition, serum-treated cultures of dissociated postnatal (P2) cerebral cortex were plated as a source of glia-enriched cultures
(Rudge et al., 1985; Fig. 2B). The majority of proteins synthesized by embryonic serum-treated cultures (Fig. $1 D$ ) were also expressed by postnatal glia-enriched cultures (Fig. $2 D: a-l, n-$ $q, x-z)$, suggesting their non-neuronal origin. However, 2 proteins, " $r$ " and "v," were not detected in glia-enriched cultures but were expressed in hormone-treated cultures with neurite outgrowth (Fig. $2 C$ ). These 2 proteins thus appear to be neuronal in origin, and to be synthesized only in association with neurite outgrowth. This idea is supported by the fact that the labeling ratio of " $r$ " (and " $v$ ") to N1 and N2, the neuronal markers, is much higher under conditions of active neurite outgrowth (see Fig. $1 D$ and $2 C$ ) than in the undifferentiated state (Fig. $1 C$ ).

Because of its association with neurite outgrowth and the similarity of its $2 \mathrm{D}$ migration position $(50 \mathrm{kDa}, \mathrm{pI} 4.7)$ to that of an identified neuronal growth-associated protein, further studies concentrated on protein " $r$." The region of the 2D fluorograms that includes this protein is shown in Figure 3. To summarize (see Table 1), this protein was detected in embryonic cortical cultures showing neurite outgrowth (i.e., in serum- and hormone-treated embryonic cultures; Fig. 3, $B$ and $C$ ) but not in embryonic cultures without outgrowth (Fig. $3 A$ ) nor in postnatal glial cultures (Fig. 3D). Under conditions in which " $r$ " was expressed, it appeared in the particulate but not the cytosol fraction of cells (Fig. $3 E$; cf. $3 B$ ). 

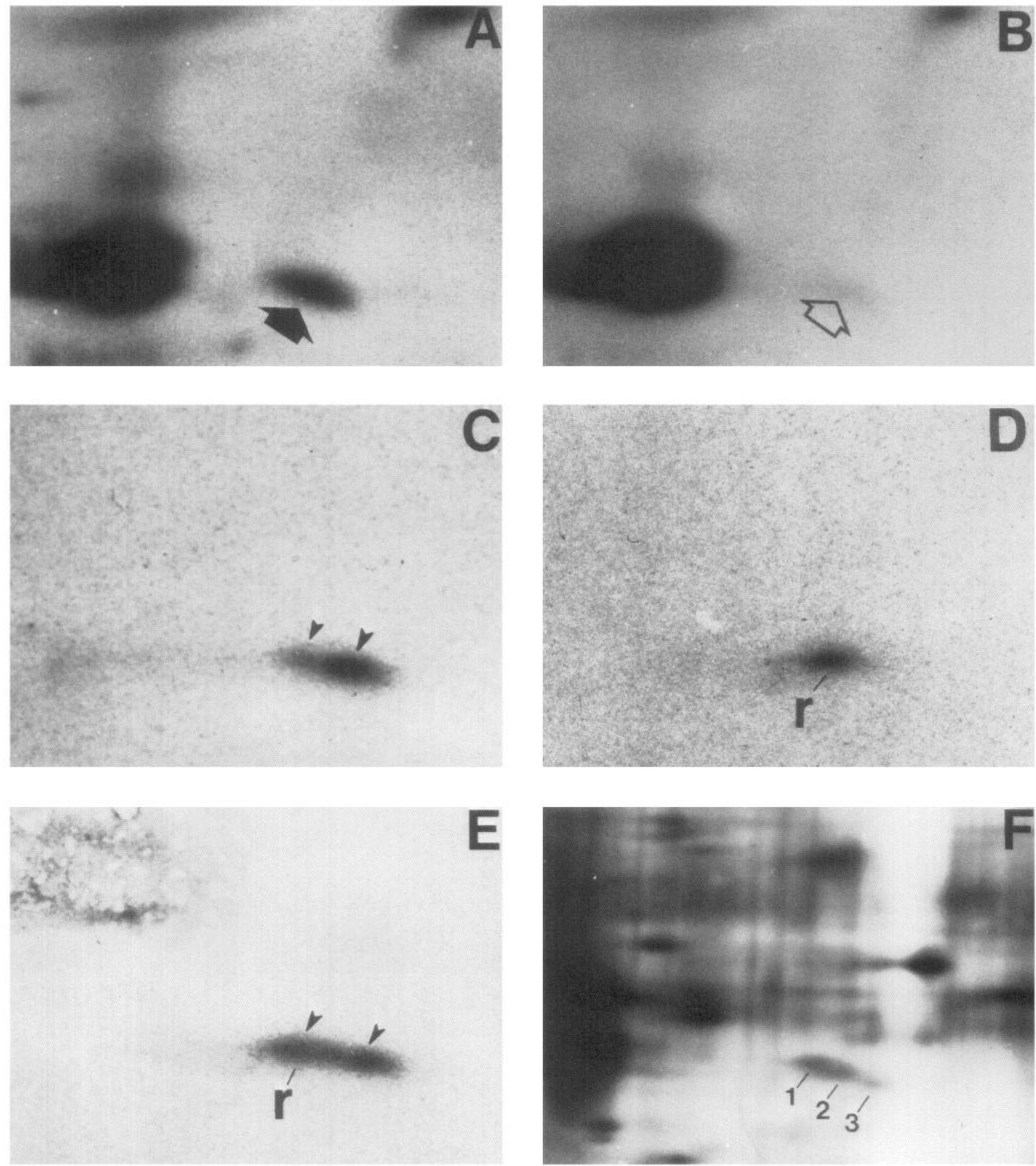

Figure 5. Comigration of protein " $\mathrm{r}$ " with the B-50 (F-1) phosphoprotein. A, Proteins of the synaptosomal plasma membrane (SPM) fraction of neonatal rat brain, phosphorylated in vitro with ${ }^{35} \mathrm{~S}-\mathrm{PO}_{3} \mathrm{~S}^{*}-\gamma$-ATP (in the presence of $1 \mathrm{~mm} \mathrm{Ca}^{+2}$ ) show the B-50 phosphoprotein migrating at MW $50 \mathrm{kDa}$, pI 4.6 (arrow). B. This protein is not phosphorylated in the absence of $\mathrm{Ca}^{2+}, 5 \mathrm{~mm}$ EGTA added (open arrow). $C$, B-50, when eluted from the original gel $(A)$ and rechromatographed, shows microheterogeneity (arrows). $D,{ }^{35} \mathrm{~S}$-methionine-labeled protein " $\mathrm{r}$," when eluted from $2 \mathrm{D}$ gels of the total particulate fraction of serum-treated embryonic cerebrocortical cultures and rechromatographed, migrates as a single spot. $E$, When approximately equal amounts of B-50 and " $r$ " were coelectrophoresed on $2 \mathrm{D}$ gels, " $r$ " appeared to be slightly more basic than the phosphorylated components of B-50. F, Silver-stained 2D gel of total particulate fractions from $48 \mathrm{hr}$ serum-treated embryonic cerebrocortical cultures shows microheterogeneity in the B-50 region $(1,2,3)$ : " $r$ " may correspond to spot 1 , the 2 phosphorylated components of B-50 with 2 and 3 . Fluorograms are representative of 2 independent replications. 


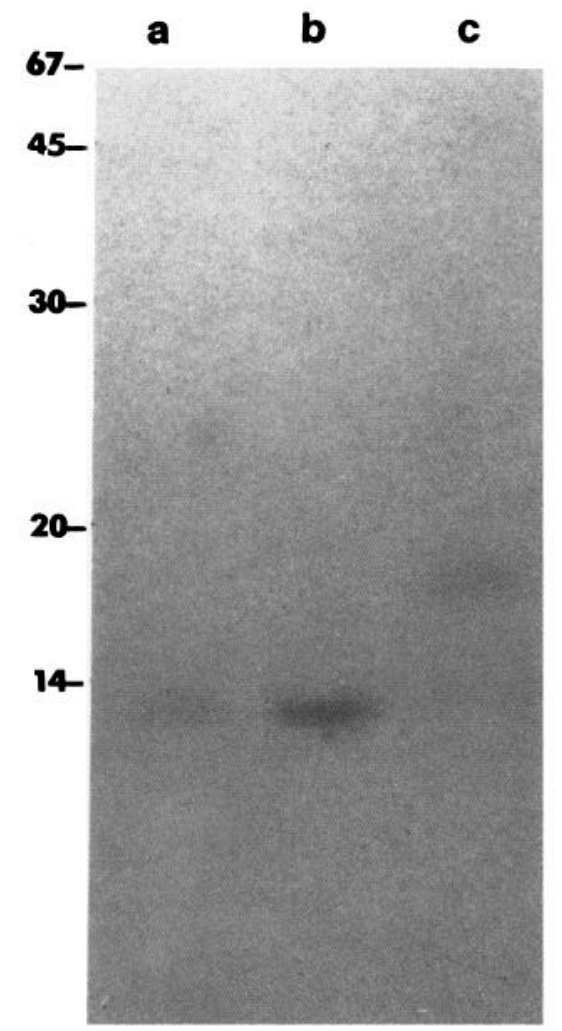

Figure 6. Proteolytic digests of the B-50 (a), " $\mathrm{r}$ " $(b)$, and " $\mathrm{q}$ " $(c)$ proteins. Labeled proteins were cut out of parent gels and digested with $S$. aureus protease. Cleavage products were run on parallel lanes of $15 \%$ polyacrylamide-SDS gels and visualized by fluorography. (Fluorograms are representative of 3 independent experiments.)

Synthesis of protein " $r$ " was seen as early as $16 \mathrm{hr}$ after plating embryonic cultures with serum, at which time neurite outgrowth was already apparent; synthesis continued at high levels for at least $6 \mathrm{~d}$, as neurons continued to elaborate a dense network of processes (Fig. 4).

\section{Comparison of protein " $r$ " to an identified phosphoprotein}

Two methods, comigration and proteolytic digestion, were used to determine whether protein " $r$ " was similar to an identified brain phosphoprotein. The B-50 or F-1 protein migrates at a position similar to " $r$ " on $2 \mathrm{D}$ gels $\left(M_{\mathrm{r}} 47-53 \mathrm{kDa}, \mathrm{pI} 4.6\right)$ and is localized in presynaptic nerve terminals of the mature brain (Gispen et al., 1985; Oestreicher et al., 1981), as well as neural growth cones of the developing brain (DeGraan et al., 1985; Katz et al., 1985; Nelson et al., 1985). The phosphorylation is calcium-dependent (Fig. 5, $A$ and $B$, arrows; Katz et al., 1985; Routtenberg and Ehrlich, 1975; Zwiers et al., 1980) and appears to involve multiple sites, associated with the microheterogeneity of the protein when visualized on 2D gels (Zwiers et al., 1985). When B-50 was eluted from unfixed 2D gels (of ${ }^{35} \mathrm{~S}_{-} \mathrm{PO}_{3} \mathrm{~S}^{*}-\gamma$ ATP-labeled neonate rat brain SPM fractions) and rechromatographed, it showed 2 labeled components (Fig. $5 \mathrm{C}$ ). Protein " $r$," eluted from gels of ${ }^{35}$ S-methionine-labeled embryonic cerebrocortical cultures (plated with serum; particulate fraction; see Fig. 1D), ran as a single spot when rechromatographed (Fig. $5 D$ ). When run together, protein " $r$ " appeared to be slightly more basic than the phosphorylated components of B-50 (Fig. $5 E$ ). Comigration gels also contained unlabeled neonatal rat brain SPM proteins. Photographic overlays of the fluorograms onto the Coomassie blue staining patterns indicated that the elongated B- 50 spot visualized by protein staining (Kristjansson
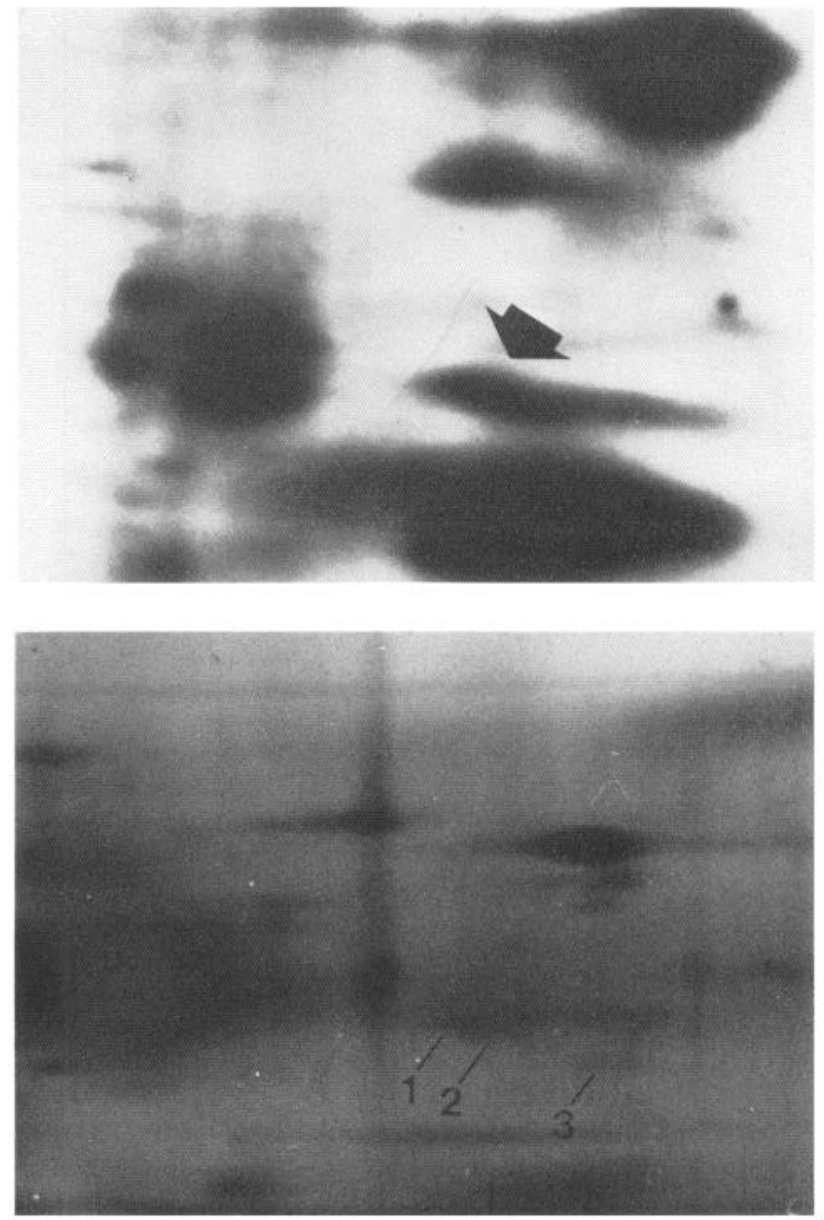

Figure 7. A, Particulate fraction from serum-treated embryonic cultures, phosphorylated in vitro with ${ }^{35} \mathrm{~S}$-ATP, shows the presence of a phosphoprotein that appears to coincide with B-50 in these cultures (arrow). B, Silver-stained gels of a light membrane fraction from these cultures shows a group of proteins $(1,2,3)$ in the position of B-50; as in Figure $5 F$, "r" may coincide with spot 1 .

et al., 1982) includes " $r$," as well as the phosphorylated components of B-50 (data not shown). Thus, "r" appears to correspond to the unphosphorylated state of B-50 that has been previously reported (Zwiers et al., 1985). Silver-stained gels of the particulate fraction of serum-treated embryonic cortical cultures revealed 3 spots in this region of the gel (Fig. $5 F$ ). The most basic of these appears to coincide with protein " $r$ " and the 2 more acidic with the phosphorylated forms of B-50.

In proteolytic digestion studies, B-50 (labeled with ${ }^{35} \mathrm{~S}-\mathrm{ATP}$ ) and "r" (labeled with ${ }^{35} \mathrm{~S}$-methionine) yielded identical $13 \mathrm{kDa}$ fragments after treatment with $S$. aureus protease (Fig. 6, $A$ and $B$, respectively). Protein " $\mathrm{q}$," which migrates close to " $\mathrm{r}$ " on 2D gels of cerebrocortical cultures (Fig. $3 B$ ), was also analyzed for its possible relationship to protein "r," but was found to have a different digestion pattern (Fig. 6c).

Additional studies show the presence of a phosphoprotein that migrates in a position similar to " $r$ " in the particulate fraction of serum-treated embryonic cultures (Fig. 7, top) and, using silver staining, the presence of a group of proteins that appears to include " $\mathrm{r}$ " in a light membrane fraction of these cells (spot 1, Fig. 7, bottom).

\section{Discussion}

The foregoing results point to a protein whose expression in embryonic rat cortical cultures is correlated with neuronal dif- 
ferentiation. By 2D gel electrophoresis, the protein migrates with an apparent molecular weight of $50 \mathrm{kDa}$ and an isoelectric point of 4.7. The protein was expressed under experimental conditions that fostered neurite outgrowth, but not under conditions without outgrowth nor in glial cultures. By several criteria, the 50 kDa protein (" $r$ " in Fig. $1 D$ ) appears to be identical to a protein that has been associated with ncuronal development, regencration, and synaptic plasticity.

These studies took advantage of the possibility of manipulating cellular composition and differentiation in primary brain culture in order to study protein synthesis patterns associated with neurite outgrowth. Our morphological and immunostaining results are consistent with previous reports showing that the majority of embryonic brain cells surviving under serum-free conditions are neurons (Barbin et al., 1984; Müller et al., 1984), while serum-treated embryonic cultures contain both neurons and glia (Raff et al., 1979), and serum-treated postnatal cultures are largely glial (Rudge et al., 1985). Generally, cultured brain cells require the addition of exogenous "trophic" and "neuritepromoting" agents (such as those provided by serum) for cellular survival and neurite outgrowth, respectively (Varon et al., 1983/ 1984); such factors may be provided by the cultures themselves, depending on cell density (Barbin et al., 1984). At the relatively high densities plated in these studies, cultures plated under each of the experimental conditions contained viable cells, as evidenced by exclusion of trypan blue and by their incorporation of ${ }^{35} \mathrm{~S}$-methionine into proteins. Cultures in "serum-free" or "hormone-supplemented" media showed 80-85\% cell survival compared to serum-treated cultures; these values were not improved by the addition of other defined media supplements (e.g., N1; Barbin et al., 1984) that enhance neuronal survival at lower densities (unpublished observations). At the densities plated, embryonic cultures in "serum-free" media showed no cellular differentiation, while those in serum- or hormone-supplemented media both showed abundant neurite outgrowth.

The $50 \mathrm{kDa}$ protein was 1 of 2 particulate polypeptides found to be synthesized selectivity in association with neuronal differentiation, i.e., it was expressed in serum- and hormone-treated embryonic cultures with neurite outgrowth but not in serumfree embryonic cultures without outgrowth or in glia.

Cerebrocortical neurons can recapitulate many aspects of normal differentiation in vitro. Whereas neurite outgrowth begins within hours, other aspects of differentiation, including the formation of electrically excitable synapses and neurotransmitter synthesis and secretion, develop only after several days in culture (Delfs et al., 1980; Dichter, 1978; Snodgrass et al., 1980). In the present study, synthesis of the $50 \mathrm{kDa}$ protein was found as early as $16 \mathrm{hr}$ after plating, in association with the beginnings of neurite outgrowth, and persisted for at least $6 \mathrm{~d}$ as cultures continued to elaborate a dense network of processes. Thus, expression of the $50 \mathrm{kDa}$ protein seems to be correlated primarily with neurite outgrowth; we have previously described a similar induction of the protein in the presence of serum in dissociated hindbrain neurons (Finklestein et al., 1985).

By several criteria, the $50 \mathrm{kDa}$ protein appears to coincide with a growth-associated, membrane-bound phosphoprotein that has been described in a number of recent studies. In mammals and lower vertebrates, the initial development and regeneration of neural pathways are characterized by high levels of synthesis and rapid axonal transport of a membranc-bound 43-49 $\mathrm{kDa}$ protein, pI 4.3-4.8 (Benowitz and Lewis, 1983; Benowitz et al., 1981; Bock et al., 1984; Moya et al., 1985; Perry et al., 1985; Skene and Kalil, 1984; Skene and Willard, $1981 \mathrm{a}, \mathrm{b})$. The synthesis of this protein declines greatly in the mature, intact state of the neuron, and, in instances in which axonal regeneration fails to occur (e.g., in the mature mammalian CNS), the protein fails to be reinduced by axotomy. These observations have led to the hypothesis that expression of the $43-49 \mathrm{kDa}$ acidic protein may be one of the basic molecular requirements of axonal outgrowth (Skene, 1984; Skene and Willard, 1981b). A similar protein has been identified as a component of the axonal growth cone in the developing mammalian brain, where it is phosphorylated by a calcium-dependent kinase (pp-46: Katz et al., 1985). The $46 \mathrm{kDa}$ growth cone protein has, in turn, been shown to bc identical to the B-50 or F-1 phosphoprotein, a membraneassociated substrate of the C-kinase (DeGraan et al., 1985; Nelson et al., 1985). Although synthesis of this protein declines greatly after birth (Jacobson and Skene, 1985), significant levels remain associated with certain central presynaptic endings (Gispen et al., 1985; Oestreicher et al., 1981). In adult rats, the phosphorylation of this protein in the hippocampal region is the most prominent molecular correlate of the elaboration and maintenance of long-term potentiation (Lovinger et al., 1985; Routtenberg and Lovinger, 1985).

The similarity between the $50 \mathrm{kDa}$ acidic protein of the present study and the identified growth-associated phosphoprotein is supported by several lines of evidence. On $2 \mathrm{D}$ gels, the 50 $\mathrm{kDa}$ protein from cultures comigrates with 1 portion of the B-50 (F1; pp-46) complex. By silver staining, this gel region shows 3 distinct spots, perhaps corresponding to the different phosphorylation states of the B-50 molecule that have been identified (Zwiers et al., 1985). One hour after pulse-labeling cultures with ${ }^{35} \mathrm{~S}$-methionine, radioactivity is concentrated in the less acidic state. The shift to more acidic, phosphorylated states may take longer, perhaps occurring in growth cones or developing synapses. Another basis for relating the $50 \mathrm{kDa}$ protein to the identified phosphoprotein is that both generate a fragment of identical molecular weight (13 kDa) after partial digestion with $S$. aureus protease. Similar digestion fragments have been described for the identified phosphoprotein by others (Katz et al., 1985; Nelson et al., 1985). Moreover, the $50 \mathrm{kDa}$ protein appears to be present in a light membrane fraction from cortical cultures, as has also been shown for the phosphoprotein (DeGraan et al., 1985; Katz et al., 1985; Nelson et al., 1985). In terms of apparent differences in the molecular weight of the $50 \mathrm{kDa}$ protein and the growth-associated protein of toad and mammalian nerves $(43 \mathrm{kDa})$, goldfish optic nerve $(48 \mathrm{kDa})$, the growth cone protein from embryonic rat $(46 \mathrm{kDa}), \mathrm{B}-50(47-53 \mathrm{kDa})$, or F-1 (47 kDa), an anomalous migration of this protein on SDS-PAGE has been demonstrated, with its apparent molecular weight varying inversely with acrylamide concentration (Jacobson and Skene, 1985; Oestreicher et al., 1981). In the present studies, the protein was visualized at the point of the gradient gels containing $8.5 \%$ acrylamide, thus yielding an apparent molecular weight slightly higher than has been reported using 10 $12 \%$ gels; anomalous SDS-PAGE migration for this protein has been found in our laboratory as well (Benowitz, Perrone-Bizzozero, and Finklestein, unpublished observations).

The present study provides evidence for a close relationship between expression of a 43-50 kDa acidic membrane phosphoprotein and the growth state of the neuron. Given the apparent significance of this protein in neural development, axonal regeneration, and synaptic plasticity, an understanding of its functional role and of the mechanisms regulating its expression is a question of increasing interest. The ease of manipulating the cellular environment and of visualizing and recording intercellular interactions in primary cortical neural cultures makes this an ideal systcm for studying thesc issucs further.

Note added in proof: The expression of the $50 \mathrm{kDa}$ "growth associated protein" (GAP-43, B-50) in primary cortical neural cultures only during neurite outgrowth has been confirmed in our laboratory by immunohistochemistry using a monospecific anti-G $\Lambda$ P/B-50 antibody, and by using a cDNA probe for the GAP/B-50 mRNA on "Northern" blots (Neve, Perrone-Bizzozero, Finklestein, Zwiers, Bird, Kurnit, and Benowitz, unpublished observations). 


\section{References}

Barbin, G., I. Selak, M. Manthorpe, and S. Varon (1984) Use of central neuronal cultures for the detection of neuronotrophic agents. Neuroscience $1: 33-43$.

Benowitz, L. I., and E. R. Lewis (1983) Increased transport of 44,00049,000 dalton acidic proteins during regeneration of the goldfish optic nerve: A two-dimensional gel analysis. J. Neurosci. 3: 3153-3163.

Benowitz, L. I., V. E. Shashoua, and M. G. Yoon (1981) Specific changes in rapidly transported proteins during regeneration of the goldfish optic nerve. J. Neurosci. 1: 300-307.

Bock, S., G. J. Snipes, J. J. Norden, and J. A. Freeman (1984) Developmental program of protein expression in rat retinal ganglion cells. Soc. Neurosci. Abstr. 10: 1030.

Cleveland, D. W. (1983) Peptide mapping in one dimension by limited proteolysis of sodium dodecyl sulfate-solubilized proteins. Methods Enzymol. 96: 223-229.

DeGraan, P. N. E., C. O. M. Van Hooff, B. C. Tilly, A. B. Oestreicher, P. Schotman, and W. H. Gispen (1985) Phosphoprotein B-50 in nerve growth cones from fetal rat brain. Neurosci. Lett. 61: 235-241.

Delfs, J., R. Robbins, J. L. Connolly, M. Dichter, and S. Reichlin (1980) Somatostatin production by rat cerebral neurones in dissociated cell culture. Nature 283: 676-677.

Dichter, M. A. (1978) Rat cortical neurons in cell culture: Culture methods, cell morphology, electrophysiology, and synapse formation. Brain Res. 149: 279-293.

Finklestein, S., N. I. Perrone-Bizzozero, and L. I. Benowitz (1985) Proteins associated with growth of rat hindbrain neurons in vitro. Soc. Neurosci. Abstr. 11: 763.

Gilbert, J. M., and P. Strocchi (1983) Studies on the cell-frec biosynthesis of CNS membrane proteins. J. Neurochem. 46: 153-159.

Gilbert, J. M., P. Strocchi, B. A. Brown, and C. A. Marotta (1981) Tubulin synthesis in rat forebrain: Studies with free and membranebound polysomes. J. Neurochem. 36: 839-846.

Gispen, W. H., J. L. M. Leunissen, A. B. Oestreicher, A. J. Verkleij, and $\mathrm{H}$. Zwiers (1985) Presynaptic localization of B-50 phosphoprotein: The ACTH-sensitive protein kinase substrate involved in rat brain phosphoinositide metabolism. Brain Res. 328: 381-385.

Jacobson, R. D., and J. H. P. Skene (1985) Developmental regulation of a growth cone membrane protein, GAP-43, in rat CNS. Soc. Neurosci. Abstr. 11:760.

Katz, F., L. Ellis, and K. H. Pfenninger (1985) Nerve growth cones isolated from fetal rat brain. III. Calcium-dependent protein phosphorylation. J. Ncurosci. 5: 1402-1411.

Kristjansson, G. I., H. Zwiers, A. B. Oestreicher, and W. H. Gispen (1982) Evidence that the synaptic phosphoprotein B-50 is localized exclusively in nerve tissue. J. Neurochem. 39: 371-378.

Lovinger, D. M., R. F. Akers, R. B. Nelson, C. A. Barnes, B. L. McNaughton, and A. Routtenberg (1985) A selective increase in phosphorylation of protein $\mathrm{F} 1$, a protein kinase $\mathrm{C}$ substrate, directly related to three day growth of long-term synaptic enhancement. Brain Res. 343: 137-143.

Moya, K. L., S. Jhaveri, G. E. Schneider, and L. I. Benowitz (1985) Protein synthesis in the retina and rapid protein transport in the developing hamster visual pathway. Soc. Neurosci. Abstr. 11: 223.

Müller, H. W., S. Seckh, and W. Seifert (1984) Neurotrophic factor for central neurons. Proc. Natl. Acad. Sci. USA 81: 1248-1252.

Nelson, R. B., and $\Lambda$. Routtenberg (1985) Characterization of protein F1 $(47 \mathrm{kDa}, 4.5 \mathrm{pl})$ : A kinase C substrate directly related to neural plasticity. Exp. Neurol. 89: 213-224.

Nelson, R. B., A. Routtenberg, C. Hyman, and K. H. Pfenninger (1985)
A phosphoprotein $(\mathrm{Fl})$ directly related to neural plasticity in adult rat brain may be identical to a major growth cone membrane protein (pp 46). Soc. Neurosci. Abstr. 11: 927.

Oakley, B. R., D. R. Kirsch, and N. R. Morris (1980) A simplified ultrasensitive silver stain for detecting proteins in polyacrylamide gels. Anal. Biochem. 105: 361-363.

Oestreicher, A. B., H. Zwiers, P. Schotman, and W. H. Gispen (1981) Immunohistochemical localization of a phosphoprotein (B-50) isolated from rat brain synaptosomal plasma membranes. Brain Res. Bull. 6: 145-153.

O'Farrell, P. H. (1975) High resolution two-dimensional electrophoresis of proteins. J. Biol. Chem. 250:4007-4021.

Perry, G. W., D. W. Burmeister, and B. Grafstein (1985) Changes in protein content of goldfish optic nerve during degeneration and regeneration following nerve crush. J. Neurochem. 44: 1142-1151.

Pfenninger, K. H., L. Ellis, M. P. Johnson, L. B. Friedman, and S. Somlo (1983) Nerve growth cones isolated from fetal rat brain: Subcellular fractionation and characterization. Cell 35: 573-584.

Raff, M. C., K. L. Fields, S.-I. Hakomon, R. Mirsky, R. Pruss, and J. Winter (1979) Cell-type specific markers for distinguishing and studying neurons and the major classes of glial cells in culture. Brain Res. 174: 283-308.

Routtenberg, A., and Y. H. Ehrlich (1975) Endogenous phosphorylation of four cerebral cortical membrane proteins: Role of cyclic nucleotides, ATP, and divalent cations. Brain Res. 92: 415-430.

Routtenberg, A., and D. M. Lovinger (1985) Selective increase in phosphorylation of a $47 \mathrm{kDa}$ protein (F1) directly related to longterm potentiation. Behav. Neur. Biol. 43: 3-11.

Rudge, J. S., M. Manthorpe, and S. Varon (1985) The output of neuronotrophic and ncuritc-promoting agents from rat brain astroglial cells: A microculture method for screening potential regulatory molecules. Dev. Brain Res. 19: 161-172.

Skene, J. H. P. (1984) Growth-associated proteins and the curious dichotomies of nerve regeneration. Cell 37:697-700.

Skene, J. H. P., and K. Kalil (1984) A "growth-associated protein" (GAP-43) in developing and severed axons of the hamster pyramidal tract. Soc. Neurosci. Abstr. 10: 1030.

Skene, J. H. P., and M. Willard (1981a) Changes in axonally transported proteins during axon regeneration in toad retinal ganglion cells. J. Cell Biol. 89: 86-95.

Skene, J. H. P., and M. Willard (1981b) Axonally transported proteins associated with axon growth in rabbit central and peripheral nervous system. J. Cell Biol. 89: 96-103.

Snodgrass, S. R., W. F. Whitc, B. Biales, and M. Dichter (1980) Biochemical correlates of GABA function in rat cortical neurons in culture. Brain Res. 190: 123-128.

Strocchi, P., V. S. Sapirstein, C. S. Rubin, and J. M. Gilbert (1984) Characterization and biosynthesis of cyclic-AMP-binding proteins in the rat central nervous system. J. Neurochem. 43: 466-471.

Varon, S., M. Manthorpe, and L. R. Williams (1983/1984) Neuronotrophic and neurite-promoting factors and their clinical potentials. Dev. Neurosci. 6: 73-100.

Zwiers, H., P. Schotman, and W. H. Gispen (1980) Purification and some characteristics of an ACTH-sensitive protein kinase and its substrate protein in rat brain membranes. J. Neurochem. 34: 16891699.

Zwiers, H., J. Verhaagen, C. J. van Dongen, P. N. E. DeGraan, and W. H. Gispen (1985) Resolution of rat brain synaptic phosphoprotein B-50 into multiple forms by two-dimensional gel electrophoresis: Evidence for multisite phosphorylation. J. Neurochem. 44: 10831090. 